\title{
Koagulasi Lateks Menggunakan Sari Pati Umbi Gadung dengan Penambahan Asam Semut
}

\section{Latex Coagulation Using Starch Extract of Gadung Tuber with the Addition of Ant Acid}

\author{
Mahdiannoor*, Nurul Istiqomah dan Rahmat Hidayat \\ Program Studi Agroteknologi Sekolah Tinggi Ilmu Pertanian Amuntai \\ ${ }^{*}$ mahdi_186@yahoo.com
}

\begin{abstract}
Gadung is one type of vine that does not get attention because it contains poison in the form of hydrogen cyanide (HCN) compounds. Gadung has a high economic value and its presence is easy to find, gadung plants have high productivity reaching 20 tons/ha when compared to cassava which is only 7.4 tons/ha. Coagulation using gadung tuber starch is natural-based coagulation that is safe for farmers even though it contains cyanide (HCN) which is toxic, but by washing hands after direct contact or after using gadung tubers, it will not be dangerous, so it is more environmentally friendly. and can be produced conventionally by farmers themselves. The aims of this study were (i) to determine the effect of giving gadung tuber starch with the addition of ant acid on latex coagulation, (ii) to get the best dose of giving various kinds of gadung tuber starch with the addition of ant acid for latex coagulation. This research was conducted in Simpang 4 Batuah Village, Raren Batuah District, East Barito Regency, Central Kalimantan Province from March to June 2020 using a completely randomized design with 5 treatments and 4 replications. The first treatment was ( $\left.p_{1}\right) 20 \mathrm{ml}$ of gadung tuber starch, $\left(p_{2}\right) 40 \mathrm{ml}$ of gadung tuber starch, $\left(p_{3}\right) 60 \mathrm{ml}$ of gadung tuber starch, $\left(p_{4}\right) 80 \mathrm{ml}$ of gadung tuber starch, and $\left(p_{5}\right) 100 \mathrm{ml}$ of gadung tuber starch. The results showed that the clumping time, the weight of the latex cup and the texture of the latex had a very significant effect, the color of the latex and the smell of the latex had no effect.
\end{abstract}

Keywords: Gadung tubers, latex, ant acid.

\section{Abstrak}

Gadung adalah salah satu jenis tumbuhan merambat yang tidak mendapatkan perhatian karena mengandung racun berupa senyawa hydrogen sianida (HCN). Gadung memiliki nilai ekonomis yang tinggi dan keberadaanya yang mudah ditemukan, tanaman gadung mempunyai produktifitas tinggi yang mencapai 20 ton/ha bila dibandingkan ubi kayu yang hanya 7,4 ton/ha. Koagulasi menggunakan sari pati umbi gadung merupakan koagulasi berbahan dasar alami yang aman bagi petani walaupun memiliki kandungan sianida (HCN) yang bersifat toksik, namun dengan mencuci tangan setelah bersentuhan langsung atau setelah selesai menggunakan umbi gadung maka hal tersebut tidak akan berbahaya, sehingga lebih ramah lingkungan dan dapat diproduksi sendiri oleh petani secara konvensional. Tujuan dari penelitian ini yaitu (i) untuk mengetahui pengaruh pemberian sari pati umbi gadung dengan penambahan asam semut terhadap koagulasi lateks, (ii) Untuk mendapatkan takaran terbaik pemberian berbagai macam sari pati umbi gadung dengan penambahan asam semut untuk koagulasi lateks. Penelitian ini dilaksanakan di Desa Simpang 4 Batuah Kecamatan Raren Batuah Kabupaten Barito Timur Provinsi Kalimantan Tengah pada bulan 
Maret sampai Juni 2020 dengan menggunakan rancangan acak lengkap dengan 5 perlakuan dan 4 ulangan. Perlakuan pertama $\left(p_{1}\right) 20 \mathrm{ml}$ sari pati umbi gadung, $\left(p_{2}\right) 40 \mathrm{ml}$ sari pati umbi gadung, $\left(p_{3}\right) 60 \mathrm{ml}$ sari pati umbi gadung, $\left(p_{4}\right) 80 \mathrm{ml}$ sari pati umbi gadung, dan $\left(p_{5}\right) 100 \mathrm{ml}$ sari pati umbi gadung. Hasil penelitian menunjukan bahwa waktu penggumpalan, bobot lateks permangkok dan tekstur lateks berpengaruh sangat nyata, warna lateks dan bau lateks tidak berpengaruh.

\section{Kata Kunci : Umbi gadung, lateks, asam semut.}

\section{PENDAHULUAN}

Tanaman gadung adalah golongan tanaman tropis yang tersebar di berbagai negara. Gadung (Dioscorea hispida Dennst) berasal dari India dan Cina Selatan kemudian menyebar ke Asia Tenggara dan Papua New Guenea. Akibat penyebaran itu, maka di beberapa daerah tanaman ini terdapat dalam jumlah signifikan dengan sebutan nama dan julukan yang berbeda. Di Indonesia tanaman ini juga memiliki beberapa sebutan antara lain sikapa (Bali dan Sulawesi) dan undo (Ambon). Di Malaysia, gadung dikenal dengan umbi arak atau gadung mabok. Di Filipina, gadung dikenal dengan nami (Tagalok), gayos (umum) dan karot (ilokana). Di Burma gadung disebut kywe dan di Thailand dikenal dengan nama Kloi. Di beberapa daerah gadung masih merupakan tanaman liar tanpa dibudidayakan dan keberadaannya kurang diperhatikan, hanya tumbuh dikebun atau dipekarangan rumah. Di beberapa daerah gadung dimanfaatkan sebagai makanan alternatif atau makanan cemilan (Lestari, Febrianti and Wiyono, 2018).

Proses penggumpalan karet didalam lateks juga dapat terjadi secara alamiah akibat aktivitas mikroba. Karbohidrat dan protein lateks menjadi sumber energi bagi pertumbuhan mikroba dan diubah menjadi asam - asam lemak eteris (asam formiat, asam asetat dan propionat). Semakin tinggi konsentrasikonsentrasi asam tersebut maka $\mathrm{pH}$ lateks akan semakin menurun dan setelah tercapai titik isoelektrik karet akan menggumpal (Manday, 2008). Penggumpalan lateks dapat terjadi karena rusaknya sistem koloid lateks. Bahan kimia yang biasa digunakan dalam penggumpalan lateks adalah asam formiat dan asam asetat (Muis, 2007).

Koagulasi lateks merupakan tahapan yang sangat penting dalam pengolahan karet alam (Havea brasiliensis) karena beberapa yang mempengaruhi modifikasi karakteristik molekuler yang dapat terjadi misalnya sifat 
- sifat dasar, karakteristik vulkanisasi, dan sifat - sifat fisik vulkanisasi karet alam. Lateks segar merupakan kaloid dari sistem emulasi di mana karet menjadi disterpersi sedangkan pendespersinya berupa cairan yang di sebut serum lateks dengan emulgator protein dan lipid. Salah satu penyebab rendahnya kualitas lateks karet alam di Indonesia disebabkan oleh pengolahan karet yang seadanya (Lestari, Febrianti and Wiyono, 2018)

Terjadinya koagulasi pada lateks karet alam dengan menggunakan sari pati umbi gadung diakibatkan oleh adanya muatan negatif pada emulgator lateks yang bereaksi dengan asam sehingga mengakibatkan terjadinya proses netralisasi dimana emulgator kehilangan muatan. Penyebab adanya muatan negatif adalah penguraian lateks sehingga lapisan pelindung partikel karet akan rusak yang menyebabkan terjadi penurunan $\mathrm{pH}$ dan interaksi antara partikel karet sehingga membentuk koagulasi (Lestari, Febrianti and Wiyono, 2018).

Salah satu faktor utama untuk menghasilkan bokar bermutu tinggi adalah penggunaan koagulan. Koagulan yang diperbolehkan adalah asam semut (asam format), asap cair dan/atau koagulan lain yang direkomendasikan oleh lembaga penelitian karet yang terakreditasi sesuai ketentuan peraturan perundang-undangan (Kemendag, 2016). Penggunaan koagulan ini disarankan tepat jumlahnya (konsentrasi larutan) agar mutu terjaga dan dapat memenuhi persyaratan standar yang telah ditentukan. Penelitian penggunaan koagulan asam semut berlebih yang telah dilakukan oleh Soesono dan Soedjono pada tahun 1975, hasilnya menunjukkan bahwa penggunaan asam semut yang berlebihan dapat menurunkan nilai plastisitas (Po dan PRI) dan meningkatkan kadar abu dan kadar zat menguap (Soeseno and Soedjono, 1975). Sedangkan penggunaan asam semut yang kurang juga akan menurunkan nilai PRI seperti yang telah dilakukan oleh (Manday, 2008).

Saat ini banyak petani masih menggunakan bahan alami atau kimia yang tidak dianjurkan seperti asam sulfat (cuka para), pupuk TSP, tawas, larutan umbi gadung, dan sari buah nanas untuk menggumpalkan lateks (Handayani, 2014). Koagulasi menggunakan sari pati umbi gadung merupakan koagulasi berbahan dasar alami yang aman bagi petani walaupun memiliki kandungan sianida ( $\mathrm{HCN})$ yang bersifat toksik, namun dengan mencuci tangan setelah bersentuhan langsung atau setelah selesai menggunakan umbi gadung maka hal tersebut tidak akan 
berbahaya, sehingga lebih ramah lingkungan dan dapat diproduksi sendiri oleh petani secara konvensional. Pemanfaatan umbi gadung dikarenakan keberadaannya yang banyak, tersebar dan mudah ditemukan serta secara ekonomis lebih menguntungkan sehingga dapat menurunkan biaya produksi (Lestari, Febrianti and Wiyono, 2018).

Penelitian ini bertujuan untuk (i) mengetahui pengaruh pemberian sari pati umbi gadung dengan penambahan asam semut terhadap koagulasi lateks, (ii) mendapatkan takaran terbaik pemberian berbagai macam sari pati umbi gadung dengan penambahan asam semut untuk koagulasi lateks.

\section{METODE PENELITIAN}

Penelitian ini dilaksanakan di Desa Simpang 4 Batuah Kecamatan Raren Batuah Kabupaten Barito Timur Provinsi Kalimantan Tengah pada bulan Maret sampai Juni 2020. Penelitian ini merupakan percobaan yang menggunakan Rancangan Acak Lengkap (RAL), dengan

Tabel 1. Rata-rata waktu penggumpalan lateks faktor tunggal yaitu perlakuan takaran sari pati umbi gadung yang terdiri dari 5 taraf perlakuan dengan 4 ulangan. Sehingga keseluruhan percobaan sebanyak 20 satuan percobaan, setiap percobaan terdiri dari 5 mangkok lum yang diamati. Taraf perlakuan sari pati umbi gadung (p) adalah sebagai berikut : $p_{1}=20 \mathrm{ml}$ sari pati umbi gadung, $\mathrm{p}_{2}=40 \mathrm{ml}$ sari pati umbi gadung, $\mathrm{p}_{3}=60 \mathrm{ml}$ sari pati umbi gadung, $\mathrm{p}_{4}=80$ $\mathrm{ml}$ sari pati umbi gadung dan $\mathrm{p}_{5}=100 \mathrm{ml}$ sari pati umbi gadung.

\section{HASIL DAN PEMBAHASAN}

\section{Hasil}

\section{Waktu Penggumpalan}

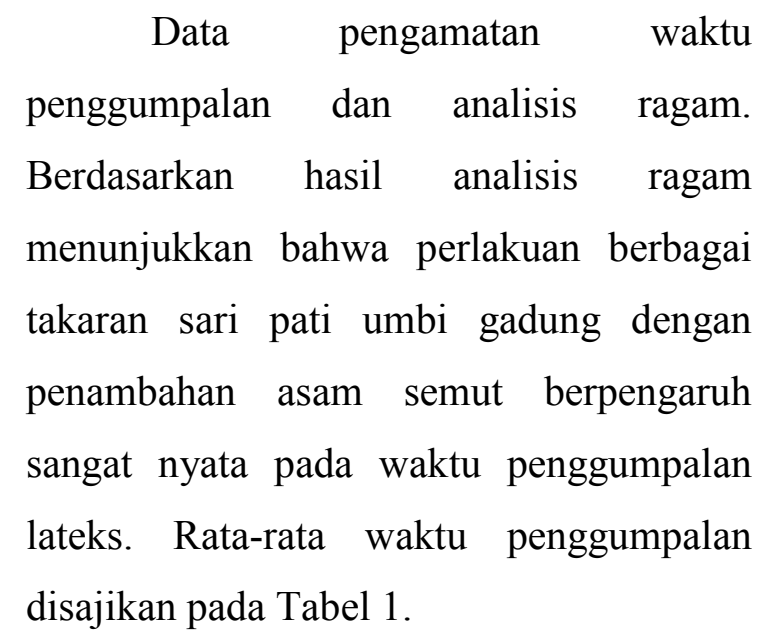
disajikan pada Tabel 1.

\begin{tabular}{cc}
\hline Perlakuan $(\mathrm{P})$ & Rata-rata waktu penggumpalan (menit) \\
\hline $\mathrm{p}_{1}$ & $24,3075^{\mathrm{a}}$ \\
\hline $\mathrm{p}_{2}$ & $20,6875^{\mathrm{b}}$ \\
\hline $\mathrm{p}_{3}$ & $19,6975^{\mathrm{b}}$ \\
\hline $\mathrm{p}_{4}$ & $17,4725^{\mathrm{b}}$ \\
\hline $\mathrm{p}_{5}$ & $17,9925^{\mathrm{b}}$ \\
\hline
\end{tabular}


Keterangan : Nilai rata-rata yang diikuti huruf yang sama menunjukkan perlakuan tersebut tidak berbeda berdasarkan uji DMRT pada taraf nyata 5\%.

Dari Tabel 1 di atas terlihat bahwa pemberian berbagai takaran sari pati umbi gadung dengan penambahan asam semut pada waktu penggumpalan perlakuan $\mathrm{p}_{4}$ menunjukan rata-rata waktu penggumpalan paling cepat yaitu 17,4725 menit tidak berbeda dengan $\mathrm{p}_{2}, \mathrm{p}_{3}$ dan $\mathrm{p}_{5}$ namun berbeda dengan $\mathrm{p}_{1}$ terhadap waktu penggumpalan. Perlakuan terbaik sari pati umbi gadung dengan penambahan asam semut untuk waktu penggumpalan adalah $\mathrm{p}_{4}$.

Tabel 2. Rata-rata bobot lateks permangkok.

\begin{tabular}{cc}
\hline Perlakuan $(\mathrm{P})$ & Rata-rata bobot lateks (gram) \\
\hline $\mathrm{p}_{1}$ & $405,5^{\mathrm{a}}$ \\
\hline $\mathrm{p}_{2}$ & $425,75^{\mathrm{a}}$ \\
\hline $\mathrm{p}_{3}$ & $465,5^{\mathrm{b}}$ \\
\hline $\mathrm{p}_{4}$ & $520,5^{\mathrm{c}}$ \\
\hline $\mathrm{p}_{5}$ & $597,5^{\mathrm{d}}$ \\
\hline
\end{tabular}

Keterangan : Nilai rata-rata yang diikuti huruf yang sama menunjukkan perlakuan tersebut tidak berbeda berdasarkan uji DMRT pada taraf nyata 5\%.

Dari Tabel 2 di atas terlihat bahwa pemberian berbagai takaran sari pati umbi gadung dengan penambahan asam semut pada bobot lateks perlakuan $\mathrm{p}_{5}$ menunjukan rata-rata bobot lateks paling berat yaitu 597,5 $\mathrm{g}$ berbeda dengan $\mathrm{p}_{1}, \mathrm{p}_{2}$, $\mathrm{p}_{3}$ dan $\mathrm{p}_{4}$ terhadap bobot lateks. Perlakuan terbaik sari pati umbi gadung dengan penambahan asam semut untuk bobot lateks adalah $\mathrm{p}_{5}$.

\section{Bobot Lateks Permangkok}

Data pengamatan bobot lateks permangkok dan analisis ragam. Berdasarkan hasil analisis ragam menunjukkan bahwa perlakuan berbagai takaran sari pati umbi gadung dengan penambahan asam semut berpengaruh sangat nyata. Rata-rata bobot lateks permangkok disajikan pada Tabel 2. 


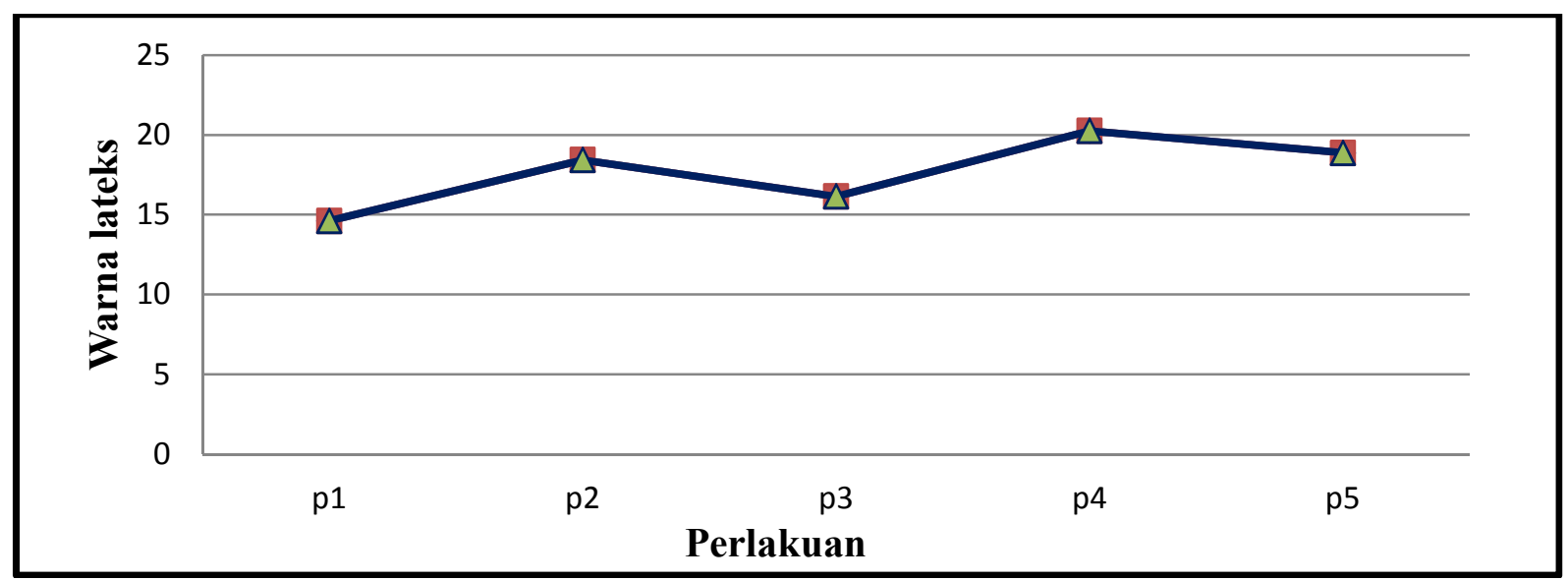

Gambar 1. Grafik pengaruh warna lateks pada berbagai takaran sari pati umbi gadung dangan penambahan asam semut.

Berdasarkan grafik diatas dapat

dilihat bahwa pemberian sari pati umbi gadung dengan penambahan asam semut dapat mengubah warna lateks pada perlakuan $\mathrm{p}_{2}$ namun mengalami penurunan pada perlakuan $\mathrm{p}_{3}$ mengalami peningkatan lagi pada perlakuan $\mathrm{p}_{4}$ kemudian menurun kembali pada perlakuan $\mathrm{p}_{5}$. Semakin tinggi takaran sari pati umbi gadung dengan penambahan asam semut maka warna lateks semakin putih kekuning-kuningan.

Tabel 3. Rata-rata tekstur lateks permangkok

\section{Tekstur Lateks}

Data pengamatan tekstur lateks dan analisis ragam. Berdasarkan hasil analisis ragam menunjukkan bahwa perlakuan berbagai takaran sari pati umbi gadung dengan penambahan asam semut berpengaruh sangat nyata. Rata-rata tekstur lateks disajikan pada Tabel 3.

\begin{tabular}{cc}
\hline Perlakuan $(\mathrm{P})$ & Rata-rata tekstur lateks \\
\hline $\mathrm{p}_{1}$ & $24,75^{\mathrm{a}}$ \\
\hline $\mathrm{p}_{2}$ & $28,5^{\mathrm{b}}$ \\
\hline $\mathrm{p}_{3}$ & $27^{\mathrm{cb}}$ \\
\hline $\mathrm{p}_{4}$ & $28^{\mathrm{b}}$ \\
\hline $\mathrm{p}_{5}$ & $30,75^{\mathrm{c}}$ \\
\hline
\end{tabular}

Keterangan : Nilai rata-rata yang diikuti huruf yang sama menunjukkan perlakuan tersebut tidak berbeda berdasarkan uji DMRT pada taraf nyata 5\%.

Dari Tabel 3 di atas terlihat bahwa pemberian berbagai takaran sari pati umbi gadung dengan penambahan asam semut pada tekstur lateks perlakuan $\mathrm{p}_{5}$ menunjukan rata-rata tekstur lateks paling keras yaitu 30,75 berbeda dengan $\mathrm{p}_{1}, \mathrm{p}_{2}, \mathrm{p}_{3}$ dan $\mathrm{p}_{4}$ terhadap tekstur lateks. makin banyak takaran sari pati umbi gadung 
maka tekstur lateks yang dihasilkan akan semakin keras. Perlakuan terbaik sari pati umbi gadung dengan penambahan asam semut untuk tekstur lateks adalah $\mathrm{p}_{5}$.

\section{Bau Lateks}

Data pengamatan bau lateks dan analisis ragam. Berdasarkan hasil analisis ragam menunjukkan bahwa perlakuan berbagai takaran sari pati umbi gadung dengan penambahan asam semut tidak berpengaruh terhadap bau lateks. Rata-rata bau lateks disajikan pada grafik berikut :

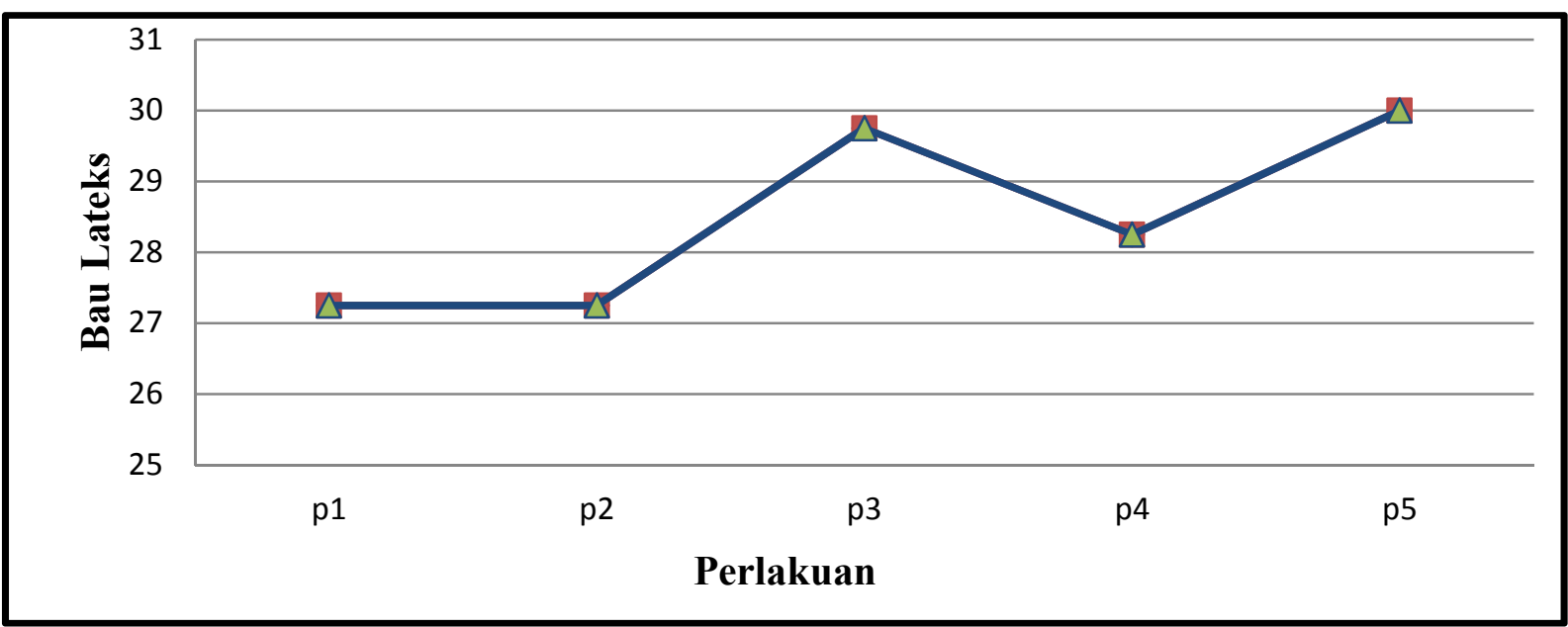

Gambar 2. Grafik rata-rata bau lateks pada berbagai takaran sari pati umbi gadung dangan penambahan asam semut.

Berdasarkan grafik di atas dapat dilihat bahwa pemberian sari pati umbi gadung dengan penambahan asam semut dapat meningkatkan bau lateks pada perlakuan $\mathrm{p}_{2}$ dan $\mathrm{p}_{3}$ namun mengalami penurunan pada perlakuan $\mathrm{p}_{4}$ dan $\mathrm{p}_{5}$. Semakin tinggi takaran sari pati umbi gadung maka bau lateks yang dihasilkan semakin masam.

\section{Pembahasan}

\section{Waktu Penggumpalan}

Berdasarkan hasil analisis ragam menunjukan bahwa koagulasi lateks menggunakan sari pati umbi gadung dengan penambahan asam semut berpengaruh sangat nyata pada waktu penggumpalan lateks. Diduga hal ini disebabkan oleh adanya reaksi netralisasi dimana emulgator dari lateks yang bermuatan negatif akan bereaksi dengan asam sehingga netralisasi dan emulgator akan kehilangan muatannya. Muatan negatif protein yang terdapat di lateks akan terurai sehingga lapisan pelindung partikel karet akan rusak jadi ketika penambahan larutan asam yang terdapat di sari pati umbi gadung terjadilah penurunan $\mathrm{pH}$ dan 
interaksi antara partikel karet sehingga membentuk koagulasi (Lestari, Febrianti and Wiyono, 2018).

Berdasarkan hasil pengamatan, mangkok lateks dengan waktu penggumpalan tercepat yaitu mangkok dengan pemberian sari pati umbi gadung dengan penambahan asam semut $85 \mathrm{ml}$ dengan rata-rata waktu penggumpalan lateks 17,4725 menit, sedangkan mangkok lateks dengan waktu penggumpalan paling lama yaitu mangkok dengan pemberian sari pati umbi gadung dengan penambahan asam semut $25 \mathrm{ml}$ dengan rata-rata waktu penggumpalan 24,3075 menit. Berdasarkan penelitian yang telah dilakukan dapat dilihat semakin banyak sari pati umbi gadung dengan penambahan asam semut maka waktu penggumpalan semakin cepat perlakuan terbaik yaitu $\mathrm{p}_{4}$ dengan takaran sari pati umbi gadung $85 \mathrm{ml}$.

Pembekuan juga disebabkan timbulnya anion dari asam lemak hasil hidrolisis lipid yang ada di dalam lateks. Sedangkan pembekuan buatan terjadi karena penambahan bahan pembeku kedalam lateks (Chusna, et. al., 2017). Ali, Sihombing and Fauzi, (2010), menyatakan lateks yang terdiri dari protein bersifat amfoter, bila ditambahkan ion $\mathrm{H}^{+}$akan terjadi penambahan muatan listrik dan akan menurunkan $\mathrm{pH}$ lateks. Semakin besar kandungan asam yang terdapat pada ekstrak gadung yang dicampurkan dengan volume lateks, maka semakin cepat lateks tersebut akan menggumpal.

\section{Bobot Lateks Permangkok}

Berdasarkan hasil analisis ragam menunjukan bahwa pemberian sari pati umbi gadung dengan penambahan asam semut berpengaruh sangat nyata pada bobot lateks permangkok. Diduga hal ini karena partikel-partikel terdispersi akan lebih mudah bergabung untuk membentuk agregat yang lebih besar sehingga menyebabkan emulsi pecah maka berat karet yang dihasilkan meningkat. berdasarkan hasil pengamatan, mangkok lateks dengan bobot lateks terberat yaitu mangkok dengan pemberian sari pati umbi gadung dengan penambahan asam semut $105 \mathrm{ml}$ dengan rata-rata bobot lateks 597,5 gram, sedangkan mangkok lateks dengan bobot lateks terendah yaitu mangkok dengan pemberian sari pati umbi gadung dan asam semut $25 \mathrm{ml}$ dengan rata-rata bobot lateks 405,5 gram. Berdasarkan penelitian yang telah dilakukan dapat dilihat semakin banyak sari pati umbi gadung dengan penambahan asam semut maka bobot lateks semakin meningkat. Perlakuan terbaik yaitu $\mathrm{p}_{5}$ dengan takaran sari pati umbi gadung $105 \mathrm{ml}$. 
Semakin bertambahnya volume ekstrak gadung maka berat karet yang dihasilkan juga semakin bertambah. Dimana, besarnya kandungan air pada ekstrak gadung yaitu sekitar $73 \%$ sehingga ekstrak gadung tersebut menyatu dengan lateks yang dapat menambah berat karet yang dihasilkan. Kondisi ini ekstrak gadung cukup stabil dan sesuai yang dibutuhkan sehingga interaksi antara air dengan asam meningkat. Oleh karena itu partikel-partikel terdispersi akan lebih mudah bergabung untuk membentuk agregat yang lebih besar sehingga menyebabkan emulsi pecah berat karet yang dihasilkan meningkat (Ali, Sihombing and Fauzi, 2010).

Pada umumnya kondisi asam ekstrak gadung meningkat interaksinya sehingga partikel-partikel terdispersinya akan lebih mudah bergabung untuk membentuk agregat yang lebih besar yang menyebabkan pecahnya emulsi dan berat karet yang dihasilkan meningkat. Asam ini bila dilarutkan dengan air akan mengion yaitu melepaskan ion $\mathrm{H}^{+}$(Ali, Sihombing and Fauzi, 2010).

\section{Warna Lateks}

Hasil analisis ragam menunjukan bahwa pemberian sari pati umbi gadung dengan penambahan asam semut terhadap warna lateks tidak berpengaruh. Di duga hal ini terjadi karena beberapa hal diantaranya adalah :

a. Kebersihan alat-alat yang digunakan dalam penyadapan dan pembekuan dapat mempengaruhi warna karet. Bila alat yang digunakan dalam penyadapan dan pembekuan tidak bersih maka lateks yang semula berwarna putih susu pada saat menggumpal akan berwarna keabu-abuan bahkan kehitaman, tergantung banyak tidaknya kotoran yang terikut. Semakin kotor alat yang digunakan maka karet .

b. kontaminan juga dapat menyebabkan perubahan warna karet. Beberapa petani bahkan dengan sengaja mencampur lateks dengan kontaminan sehingga pada saat menggumpal karet lebih berat. Tetapi hal tersebut menyebabkan warna karet tidak putih lagi dan bahkan dapat menurunkan harga karet. Beberapa kontaminan yang biasa ada dalam karet adalah daun, kulit pohon, kayu dan batu. Pabrik memang menerima karet kotor yang dijual petani, tetapi biasanya harga karet yang putih bersih akan lebih tinggi dibanding karet yang kotor. Hal tersebut berhubungan dengan kadar karet kering (KKK), biasanya KKK karet yang putih bersih lebih tinggi 
dibanding karet yang kotor (Chusna, et, al., 2017).

Jika dilihat dari tekstur warna lateks yang menggunakan cuka sintetis menunjukan warna koagulasi putih namun terdapat warna ungu disela - sela koagulasi yang membuat lateks kelihatan kotor sedangkan yang menggunakan sari pati umbi gadung berwarna putih. Kriteria warna yang sempurna ketika koagulasi karet tersebut memiliki kriteria warna putih (Wiyono, et. al., 2016).

\section{Tekstur Lateks}

Berdasarkan hasil analisis ragam menunjukkan bahwa pelakuan sari pati umbi gadung dangan penambahan asam semut berpengaruh pada tesktur lateks. Diduga hal ini disebabkan lateks yang terdiri dari protein bersifat amfoter, bila ditambahkan ion $\mathrm{H}^{+}$akan terjadi penambahan muatan listrik dan akan menurunkan $\mathrm{pH}$ lateks sampai pada titik isoelektrik sehingga partikel karet menjadi tidak bermuatan. Protein pada lateks yang kehilangan muatan akan mengalami denaturasi sehingga selubung protein yang berfungsi melindungi partikel karet akan terjadi tumbukan yang menyebabkan tekstur lateks mengeras. Lateks terjadi di daerah dimana potensial tidak mantap (stabil) yang dinamakan daerah potensial stabilitas kritis yaitu dengan $\mathrm{pH}$ sekitar 3,7 sampai 5,5 (Ali, Sihombing and Fauzi, 2010).

Hasil pengamatan tekstur lateks paling keras yaitu pada perlakuan $\mathrm{p}_{5}$ dengan ratarata tekstur 30,75 sedangkan tekstur lateks terendah pada perlakuan $\mathrm{p}_{1}$ dengan ratarata tekstur 24,75. Semakin banyak takaran sari pati umbi gadung dengan penambahan asam semut tekstur lateks semakin keras. Perlakuan terbaik sari pati umbi gadung dengan penambahan asam semut untuk tekstur adalah $\mathrm{p}_{5} 105 \mathrm{ml}$ sari pati umbi gadung.

Sedangkan sari pati umbi gadung menurut Ali, Sihombing and Fauzi, (2010) menyebabkan hasil bekuan lebih keras dibandingkan dengan hasil bekuan dengan pembeku lain disebabkan karena adanya reaksi netralisasi dimana emulgator dari lateks yang bermuatan negatif akan bereaksi dengan asam sehingga netralisasi dan emulgator akan kehilangan muatannya sehingga terjadi pengerasan pada lateks.

\section{Bau Lateks}

Berdasarkan hasil analisis ragam pemberian sari pati umbi gadung dangan penambahan asam semut tidak berpengaruh pada bau lateks. Di duga hal ini terjadi karena kadar nitrogen, dimana kadar nitrogen pada sari pati umbi gadung 
sedikit lebih rendah sebesar 0,22. Bau adalah salah satu indikator bahwa telah terjadi aktifitas mikroba pada proses prakoagulasi pada karet. (Praharnata, Sulistyo and Wijayanti, 2016).

Kegiatan penyadapan lateks maupun pengolahan lateks dapat menimbulkan bau. Sumber dari bau tersebut diantaranya adalah lateks segar itu sendiri, bahan pembeku yang digunakan, dan karet hasil pembekuan lateks (Chusna, 2017). Koagulasi lateks menggunakan umbi gadung yaitu sedikit bau asam sedangkan koagulasi lateks menggunakan asam semut yaitu asam menyengat (Chusna, et. al., 2017).

Bau busuk menyengat terjadi karena pertumbuhan bakteri pembusuk yang melakukan biodegradasi protein di dalam bokar menjadi amonia dan sulfida. Hal tersebut terjadi karena bahan pembeku lateks yang digunakan tidak dapat mencegah pertumbuhan bakteri. Bahan pembeku yang dianjurkan adalah yang mengandung senyawa-senyawa yang dapat berfungsi sebagai antibakteri dan antioksidan. Senyawa yang berfungsi sebagai antibakteri adalah fenol dan turunannya, yang akan membunuh bakteri didalam lateks dan bekuan sehingga tidak terjadi bau busuk (Chusna, et. al., 2017).

\section{SIMPULAN}

1. Diketahui adanya pengaruh sari pati umbi gadung dengan penambahan asam semut untuk koagulasi lateks pada waktu penggumpalan, bobot lateks dan tekstur lateks.

2. Takaran terbaik sari pati umbi gadung dengan penambahan asam semut terhadap koagulasi lateks pada perlakuan $\mathrm{p}_{5}$ setara dengan $100 \mathrm{ml}$ sari pati umbi gadung.

\section{DAFTAR PUSTAKA}

Ali, F., Sihombing, A. and Fauzi, A. (2010) 'Koagulasi lateks dengan ekstrak gadung (Dioscorea hispida Dennts)', Jurnal Teknik Kimia, 17(3).

Handayani, H. (2014) 'Pengaruh berbagai jenis penggumpal padat terhadap mutu koagulum dan vulkanisat karet alam', Jurnal Penelitian Karet, pp. $74-80$.

Kemendag (2016) Peraturan Menteri Perdagangan RI No. 54/MDAG/PER/7/2016 tentang Pengawasan Mutu Bahan Olah Karet Spesifikasi Teknis yang diperdagangkan. Jakarta: 
Kementerian Perdagangan

Republik Indonesia.

Lestari, F., Febrianti, Y. and Wiyono, J. (2018) 'Pemanfaatan Sari Pati Umbi Gadung (Dioscorea hispida Dennst) Untuk Koagulasi Lateks Karet Alam (Hevea brasiliensis)', Jurnal ilmiah biologi, 6(1), pp. 23-27.

Manday, P. B. (2008) 'Pengaruh penambahan asam formiat sebagai koagulan terhadap mutu karet', Karya Ilmiah. Departemen Kimia Program Studi Diploma-3 Kimia Fakultas Matematika dan Ilmu Pengetahuan Alam. Universitas Sumatera Utara. Medan.

Muis, Y. (2007) 'Pengaruh penggumpal asam asetat, asam formiat, dan berat arang tempurung kelapa terhadap mutu karet', Jurnal Sains Kimia, 11(1), pp. 21-24.

Praharnata, P., Sulistyo, J. and Wijayanti, H. (2016) 'Pengaruh Penggunaan Nanas Dan Umbi Pohon Gadung Sebagai Koagulan Terhadap Kualitas Bahan Olahan Karet Rakyat', Konversi, 5(1), pp. 30-38.

Soeseno, S. and Soedjono, I. (1975) 'Pengaruh $\quad \mathrm{pH}$ terhadap penggumpalan lateks kebun dan sifat karet yang diperoleh', Menara Perkebunan, 43(3), pp. 133-139. 